\title{
Study of parental models: building an instrument for their exploration
}

\author{
ESTUDO DA MODELAGEM PARENTAL: A CONSTRUÇÃO DE UM ESTUDO PARA A \\ EXPLORAÇÃO
}

\section{ESTUDIO DE MODELOS PARENTALES: LA CONSTRUCCIÓN DE UN INSTRUMENTO PARA SU EXPLORACIÓN}

\section{José Francisco Martínez Licona', Aracely Díaz Oviedo², Aileen Azucena Salazar Jasso², Marcela Duron Rivera ${ }^{3}$}

\section{ABSTRACT}

Objective: This research presents the construction of an attributional questionnaire concerning the different parental models and factors that are involved in family interactions. Method: A mixed methodology was used as a foundation to develop items and respective pilots that allowed checking the validity and internal consistency of the instrument using expert judgment. Results: An instrument of 36 statements was organized into 12 categories to explore the parental models according to the following factors: parental models, breeding patterns, attachment bonds and guidelines for success, and promoted inside family contexts. Analyzing these factors contributes to the children's development within the familiar frown, and the opportunity for socio-educational intervention. Conclusion: It is assumed that the family context is as decisive as the school context; therefore, exploring the nature of parental models is required to understand the features and influences that contribute to the development of young people in any social context.

\section{DESCRIPTORS}

Family

Child rearing

Family relations

Questionnaires

\section{RESUMO}

Objetivo: Construir um questionário para identificar os padrões de reprodução, de apego e de sucesso que moldam os pais na interação familiar atualmente. Método: Uma metodologia mista foi utilizada na elaboração dos itens, e posteriores testes pilotos para a validação e consistência interna do instrumento, avaliado por um júri, constituído por especialistas. Resultados: Obteve-se um instrumento com 36 declarações, organizadas em 12 agrupamentos para a exploração de modelos familiares, de acordo com os fatores: criação dos filhos, laços familiares e os padrões de sucesso, existentes em contextos familiares e cada um deles com suas respectivas dimensões. A análise desses fatores forneceu informações sobre a natureza da formação da família nuclear e as áreas de oportunidade para a intervenção socioeducativa. Conclusão: Neste trabalho assume-se que o contexto familiar é tão decisivo como o contexto escolar, sendo assim, explorar a natureza dos modelos familiares, atualmente, é necessário para o conhecimento das características e influências da formação dos jovens, em qualquer contexto social.

\section{DESCRITORES \\ Família \\ Educação infantil \\ Relações familiares \\ Questionários}

\section{RESUMEN}

Objetivo: Construir un cuestionario para identificar los patrones de reproducción de apego y de éxito que forman los padres en la interacción familiar en la actualidad. Método: De corte mixto para elaboración de ítems, con pruebas piloto para validez y consistencia interna del instrumento y evaluación por un jurado compuesto por expertos. Resultados: Se obtuvo un instrumento con 36 enunciados, organizados en 12 grupos para la exploración de modelos familiares, conformado por los factores: crianza de los hijos, los vínculos familiares y los patrones de éxito existentes en contextos familiares y cada uno de ellos con sus respectivas dimensiones. El análisis de estos factores proporciona información sobre la naturaleza de la formación de la familia nuclear y las áreas susceptibles de intervención socioeducativa. Conclusión: En este trabajo se parte del supuesto de que el contexto familiar es tan determinante como el contexto escolar, por lo tanto, explorar la naturaleza de los modelos familiares en la actualidad, es necesario para el conocimiento de las características e influencias de la formación de los jóvenes, en cualquier contexto social.

\section{DESCRIPTORES \\ Familia \\ Crianza del niño \\ Relaciones familiares \\ Cuestionarios}

\footnotetext{
${ }^{1}$ Full-time Research Professor, Institute of Research of School Psychology, University Autonomy of San Luis Potosi México. jfmartinez@uaslp.mx ${ }^{2}$ Full-time Research Professor, School of Nursing, University Autonomy of San Luis Potosi México. ${ }^{3}$ Masters student the Institute of Research of School Psychology,
} University Autonomy of San Luis Potosi México.

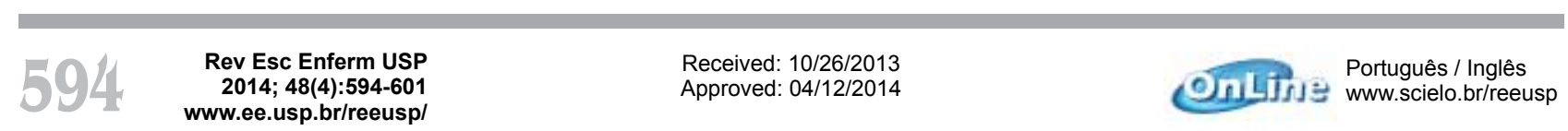




\section{INTRODUCTION}

The family is the only universal institution that is evident in all societies; every human being is born to a family, and the majority of families are created on their own. According to the Interamerican Institute of Child ${ }^{(1)}$, the family is defined as

a group of people living under the same roof, organized into --- roles (father, mother, brothers, etc.) affiliated by consanguinity, affinity or co-residence, with an economic and social common existence with emotional feelings that join them together.

Although there are different types of families, such as nuclear, single-parent and extended ${ }^{(2)}$ families and other alternative models, families maintain their role in socializing and implementing their values through their day-today living experiences and according to their particular way of life. Thus, the family transmits their social status to the children and influences their future decisions.

Research has focused on the functions and factors that influence the development and growth of children within the family, given its importance as the primary reason for its existence. Because of the helplessness of human breeding at the time of a child's birth and the slow development of independence and autonomy ${ }^{(2)}$, the family is the first and primary socialization context that serves as a constant environment. In the context of the family in which people live, there are essential components, such as providing love and therefore emotional security for children, teaching the initial and the most basic individual routines and familiarizing children with the importance of adhering to the rules and conventions of the social world ${ }^{(3)}$.

An important component of the family is the maintenance of mental health practices, which is based on attachment, co-responsibility, involvement and knowledge of what the family group brings regarding the overall health of its members. For example, when one family member presents some pathology, it is necessary to maintain a committed relationship among the multidisciplinary medical team, patients and families, thereby enabling effective, sincere, responsible and meaningful communication, interaction, and social network ${ }^{(4)}$.

The importance of establishing parental models that are promoted within the family dynamics creates a vital research direction for proposing sets of action lines in the family context that impact the individual's personal and social development. This questionnaire proposes an instrument for helping professionals work closely with Mexican families and identifying those factors that are involved in shaping parental models, which are necessary for understanding the educational background that influences individuals in their daily performance. Additionally, this questionnaire delineates the process of building the instrument and describing their functions and characteristics.
Two suggested dimensions of parental models are related to the combination of two components: the affective identity and behavior control. Therefore, parental affection should be treated as behavior that parents show their children, whereby the children feel that they are loved and feel accepted as individuals within the family; the parental control (discipline) is a key factor for achieving the socialization of children and promoting interaction between children's behavior and behavioral values. Parental control refers to the type or degree of intensity in an attempt to influence parents in the children's behavior ${ }^{(3)}$.

In previous studies concerning parental models, models have emerged that support three parenting styles: authoritarian (emphasizes control and obedience), permissive (emphasizes self-expression and self-regulation), and authoritative (emphasizes mixed respect regarding the child's individuality and the inculcation of social values). The presence of each level of control depends on the level of responsiveness and which parent was involved; these the previous studies propose that paternal practices can be described by two basic dimensions ${ }^{(3,5)}$ :

a) Requirement: not parental exigency, demands; no demands.

b) Responsiveness: no parental responsibility, willingness, interest; not dispositions, not interested in obtaining the following disciplinary styles:

i) Authoritative: reciprocal;

ii) Authoritative: repressive;

iii) Permissive: indulgent; and

iv) Permissive: negligent.

Similarly, another study presented five parental models: authority model, democratic model, permissive or indulgent model, negligent model and survival model(6). The parental style typologies were characterized according to the manner in which the parents applied rules to their children concerning controlling behavior at home, and these styles were often transferred to other social or educational contexts. Concerning the difficulties of effective parental models, the acceptance of rules and parental demands depends on the following four aspects ${ }^{(6)}$ :

- There is a warm and harmonious emotional climate in the family interaction.

- The child perceives the requirement of rules and parental demands as appropriate and fair, according to his or her behavior and situation.

- The child is motivated to obey.

- The child attributes positive intentions to the parents.

Although a confrontation may exist between the traditional and recently emerged parental models, to maintain a healthy relationship between parents and children, there should not be such a confrontation between the two dimensions that constitute authority, i.e., power and love. Authority is not the exercise of only power, but more 
importantly, it is the exercise of love. According to the breeding patterns, what are convenient is a combination of sensitivity and control, confidence and warmth and a mix of power and affection.

It is necessary to understand the perceptions that individuals attribute to themselves to guide their behavior in various scenarios, such as family, school and society, thus leading to the study of how thoughts are organized in such a way to develop common sense.

As a result of their daily lives, people construct representations of reality and use their cognitive processes to interpret situations, predict and understand the behavior of others and plan their own behavior. Individuals create ideas, beliefs or theories that they ultimately use to conduct themselves in their daily lives ${ }^{(7)}$. Mental constructs that result from cultural activities and practices support two functional levels of thoughts: the representational and the attributional. The first level, representation, is evident when a person uses knowledge to declare or recognize something, whereas the attributional level is used pragmatically to plan his or her behavior ${ }^{(8)}$. The difference between both levels will be a function of what is demanded, either theoretical or pragmatic guidance (ibid).

In the representational function, verbal communication is an important tool; the execution of actions reveals the attributional function. This premise considers that people can recognize different prototype versions of knowledge (representation); however, several versions (attributional) are only assumed to be their own ${ }^{(8)}$. Under this attribution scheme, as in the case of the instrument, we can reveal the conduct of self-practice, which in turn may evoke reference to or awareness of the world. Through attribution, we realize the appropriateness of these representations, so that the role of attributional thinking is the basis for one's actions, as opposed to a demand.

Based on this theoretical framework of the organization of thought and knowledge concerning factors that are involved in parental models and how these models are executed, the present study aims to construct an exploratory instrument for to identify thing breeding patterns, attachment bonds and standards of success that are instrumental in shaping the parental models that families use today.

\section{METHOD}

A mixed methodology was used to explore the attributional instruments ${ }^{(9)}$. Subsequently, a theoretical review and cultural analysis were performed because a key element in this process is to understand what belief systems exist in daily thinking concerning the breeding patterns, attachment bonds and standards of success with respect to parents. The construction stages for the instrument are shown in Figure $1^{(9)}$.

\section{Population}

The fathers and mothers live in different urban areas and conurbations of the city of San Luis Potosi, México, including a diverse range of families with different biographical, economical and social characteristics. Before the development of this research project, a protocol was sent to the Research and Ethics Committee of the University of San Luis Potosí to obtain the registration approval for the project. The protocol met the criteria and standards established for the implementation of project CEI-0056FEUASLP.

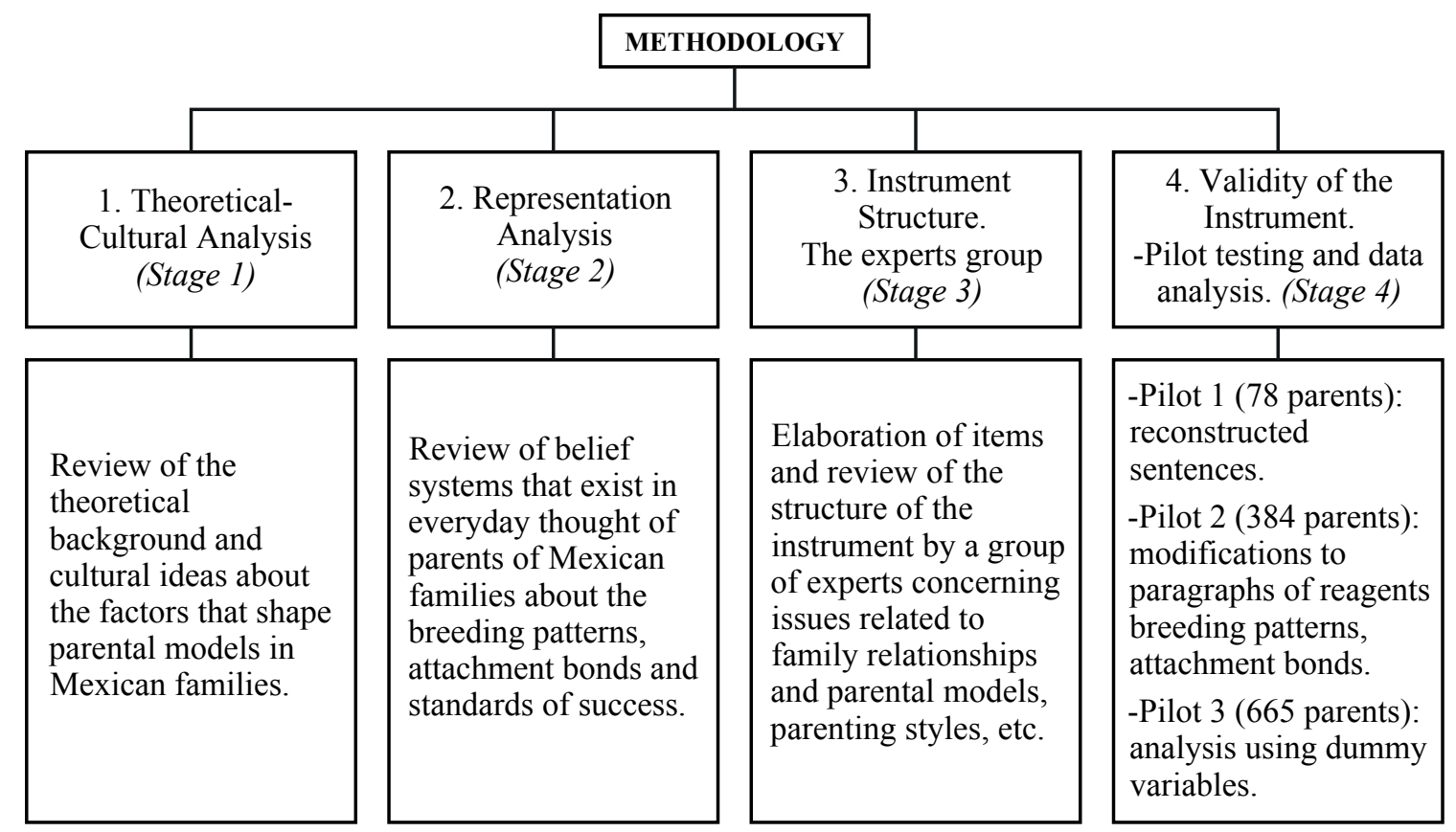

Figure1 - Construction of the instrument based on the methodology of Camacho and Correa ${ }^{(9)}$. 


\section{First stage}

The first stage was a recovery of cultural history concerning different theoretical contributions; the research focused on the characteristics of family gatherings that are described in the parental models, parenting styles, and family ties. The aim was to develop a comprehensive image that allowed shafts of rationality by which to conduct an initial exploration to better understand the content and specific manifestations from different patterns that shaped later reference groups regarding the styles of each factor involved.

\section{Second stage}

Once the information from the first phase was obtained and a guide over the rationality shafts involved in family life and a representational analysis were performed, 60 semi-structured interviews were conducted in a selected convenience sample comprising families from different backgrounds and characteristics. The topic focused on the issues that the families considered important in terms of standards, discipline and scenarios in which they are set, and the distribution of tasks, rights and obligations, efforts for promoting success in children, forms of affection, simultaneously sharing in family communication, among others that might contribute to the family dynamics.

For the interview analysis, a group of experts was established to present themes related to family relationships, child nurturing, parental models, family models, and parenting styles, which were reviewed, discussed and categorized relative to the discourse obtained from the interviews.

With this review and the discussion of the cultural and representational analyses and based on the discourse obtained in the interviews, it was proposed that the components of the questionnaire be divided into three primary groups: upbringing patterns, attachment bonds and guidelines for success, elements that are related and integrated to form and define profiles in relation to a parental model. The topic of upbringing patterns was approached using the following dimensions: a) normative: limits and rules, and b) disciplining: control and discipline in three different environments: the family context (home), the social context and the school context. The topic of attachment bonds was addressed using the following three dimensions: a) temporary, b) emotional, and c) communicative. Finally, the guidelines for success were related to the following dimensions: a) normative: pattern and promotion, and b) disciplining: control and evaluation.

\section{Parental factors were defined as follows:}

\section{Breeding patterns}

- Rigid: The pattern of nurturing defines a culture of coexistence that is based on order and respect as well as compliance with the standards imposed by the parents, with inflexible boundaries and minimal justification; obedience and respect for parental authority is fundamental in family dynamics; and adherence to the rules is justified considering the children's welfare and its breach has consequences.

- Negotiator: The breeding patterns incorporate principles, rules and limits that are negotiated because of the children's needs and the parents' claims. This type of breeding patterns promotes interdependence between parents and children through exchanges that prevail; and explicit rationalization and respect for the rules and the consequences can result in certain types of behaviors in children.

- Indulgent: In this type of breeding patterns, the parents rely on their children for making decisions independently, leaving ample scope for what children can do. The children enjoy a generous freedom of action and are driven by their interests and impulses; there are few rules and following the rules generates no restrictions or punishment.

\section{Attachment bonds}

- Warm: The displays of affection among parents and children are distinguished by being part of everyday life and are characterized by being constantly full of warmth and closeness with time and communication available at all times.

- Closer: Parents share affection, particularly spontaneous and sporadic affection, with their children with enough time and communication.

- Elemental: Parents demonstrate minimal signs of affection and time spent with their children with almost no communication among them.

\section{Guidelines for success}

- Promoter: Accompanies and assists in decisions that children make regarding their interests and patterns of family success.

- Guiding: Collaborates and supports in building successful patterns for their children, considering their children's interests.

- Condescending: Accepts the decisions and initiatives independently related to the success patterns of their children.

- undifferentiated attribution: Claims no particular success pattern, and its decisions on the promotion, control and evaluation of the guidelines for success most likely depend on other factors, such as the situation or mood.

\section{Third phase}

Using the elements obtained from the previous phase, a series of statements was used to explore each dimension 
and its individual components. An initial instrument was developed that contained attributions for all of the dimensions for each factor. There were four exclusionary statements regarding the characteristics of family life, and the interviewees were asked to identify the factor that most frequently occurred in their family. The questionnaire contained 48 statements; each subject included thirteen factors and dimensions. This questionnaire was used as a tool to investigate the guidelines for success in each family.

\section{Fourth phase:}

First piloting: In the initial version of the instrument construction, to obtain an attributional analysis of the founded arguments in a representational analysis, an application was assigned to 78 parents as its first pilot. After analyzing the results from the first application and a test performed by qualified professionals it was necessary to reformulate several statements and omit others because of its lack of clarity. Making the appropriate changes in the application, interpretation and validation of the instrument reduced the total number of statements in the questionnaire from 48 to 36 , thus keeping multiple choice format of the tool referred to as the promoted pattern of success in each family. This phase was noted in the information processing, and a statistical analysis was performed using ranges; according to the score of each subject, this assignment was categorized as one style in each factor.

Second piloting: The modified instrument, according to the observations and results from the first pilot program, was applied to 384 parents with characteristics similar to the above model.

After analyzing the results and the information obtained, this second pilot allowed us to make the latest modifications in the writing style in several categories whose similarity would threaten the clarity of the instrument. In addition to noting the most important changes in the data analysis and parsing through ranges of scores and the classification of each subcategory, we observed several deficiencies when grading the subjects. The allocation of each subject to the child rearing styles was not assigned in a coherent way, e.g., the bonds of affection and the patterns of success, because in several cases, the location of each subject with regard to the ranges of each factor score did not match with the majority of the responses expressed by the subjects.

\section{First study}

In a third version of the instrument and final modifications, we applied the questionnaire for the third time to 665 parents, 165 fathers and 500 mothers aged between 20 years and 70 years, in the city of San Luis Potosi and conurbation area. This time, the instrument was used to analyze with the dummy variables, which are scored with the number 1 for each selected item and 0 for the other options, using compliance conditions of responses per reac- tive, to attribute the style guidelines parenting, attachment bonds and guidelines for success according to the largest number of responses from each style, avoiding evaluative biases through the ranks. Thus, we decided to consider as many answers as possible to determine the category in which each subject is located, as it is a cutting-edge attributional questionnaire in which the uniformity of responses for each factor represents the affinity parental model.

\section{Analysis and information processing: Validation}

During its construction, the instrument was submitted to a validation content using an expert judgment procedure, which is usually applied for this type of construction, through content validity is to determine where the items of an instrument are representative of the domain or universe of content is the property to be measured ${ }^{(10)}$. Unlike other types of validity, the content cannot be expressed quantitatively because it relates to a matter of judgment that is estimated subjectively or inter-subjectively. For this process, we selected specialists to work with Mexican families, which included a group of 12 psychologists. Following the recommendations proposed, the psychologists were chosen for their expertise on the subject and for their educational background (PhD) and affiliation with a research group in a recognized academic institution ${ }^{(11)}$.

\section{RESULTS}

Based on the results of the first study, we were able to validate the content, construct the instrument and assess an internal consistency using expert judgment and analyses, which revealed that the instrument is capable of discriminating responses between the subcategories.

Although the application does not yield a parental model that is shared predominantly, as expected, given the social and dynamic characteristics of today's families, the application does make a distinction between attachment bonds, parenting guidelines and guidelines for success because can identify the type of parental factor that involves each family with respect to educational patterns.

Similarly, a fourth category in each subscale called Eventual (ascription undifferentiated) appeared, in which there were parents who scored indifferently in varied styles, without showing a clearly defined linking type, breeding patterns, attachment bonds or guidelines for success. Depending on the demand in each situation, the parental model style involving the family during the time they lived together caused a certain distress in the internal consistency of the instrument and its prevalence was not significant in relationship to other parents. We confirm that we have obtained an exploratory instrument for educational purposes that describes the parental models that are beneficial for parents and mothers and that identifies the breeding patterns, attachment bonds and guidelines for success that parents value in educating their children. 


\section{Study outcomes}

- It does not feature a predominant parental model; however, there are models that families share more often.

- The most recognized attribution by parents in each category is identified.
- Although the study may not present a generalized model, the combination indulgent-negotiator/elemental and guiding model is most often shared.

Figure 2 shows the final structure of the instrument.

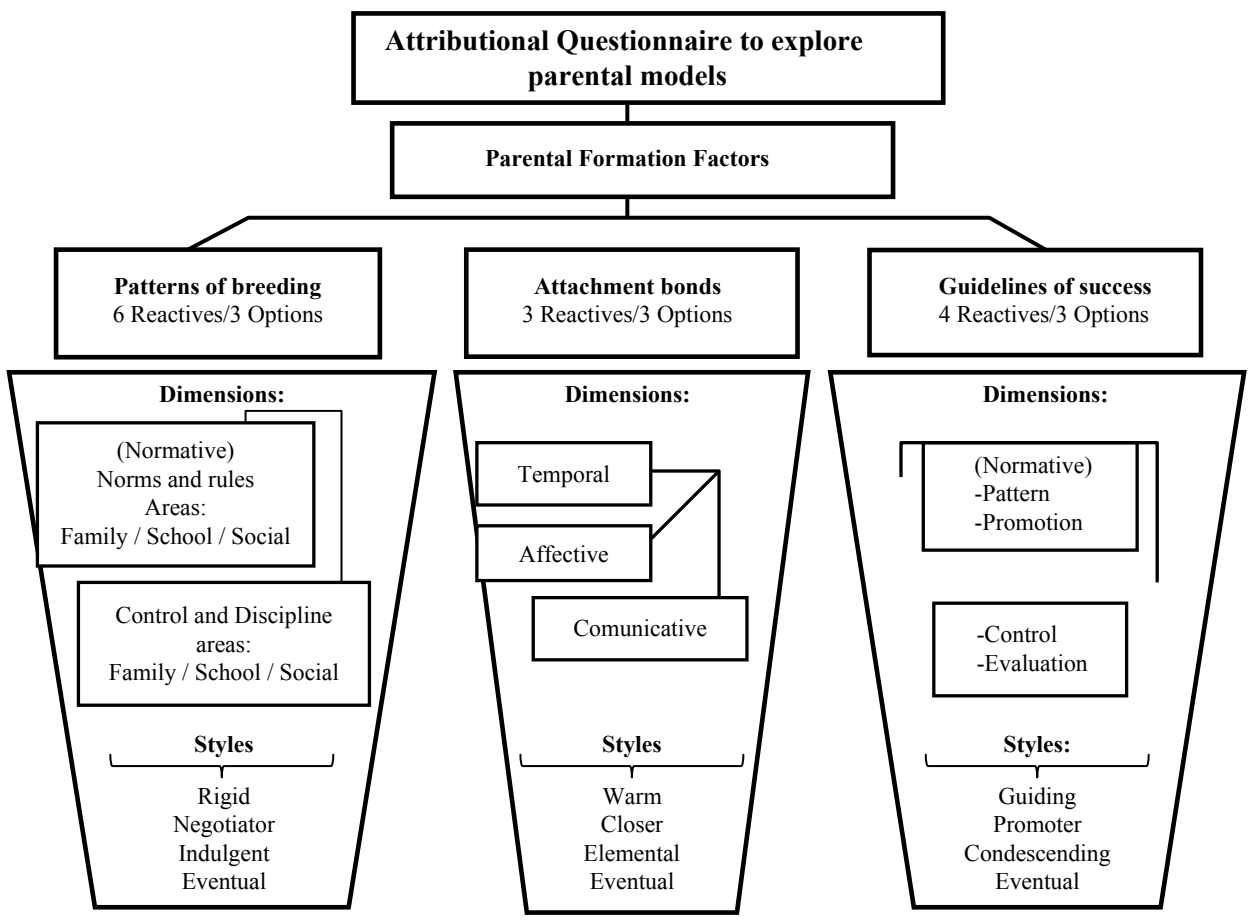

Figure 2 - Structure of the instrument.

\section{Presentation of the Final Instrument: identifying information:}

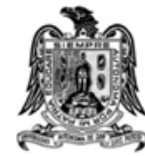

UNIVERSIDAD AUTÓNOMA DE SAN LUIS POTOSÍ INSTITUTO DE INVESTIGACIÓN Y POSGRADO CUESTIONARIO ATRIBUCIONAL PARA LA EXPLORACIÓN DE MODELOS PARENTALES

Datos generales Madre ( ) Padre( ) Edad: Estado civit: Ocupación: Colonia donde vive: Número de hijos:___ Hombres___ Mujeres___ Edad de los hijos: Escolaridad de todos los hijos:

Marque con una $\mathrm{X}$ el tipo de Modelo familiar al que pertenece su familia:

Familia nuclear ( ) Familia Monoparental ( ) Familia Extensa ( ) Familia reconformada ( ) Otra ( )
¿Quién aporta el ingreso familiar?

Comúnmente ¿Quién pone las normas y reglas en su familia?

Lea las siguientes afirmaciones y marque con una " $\mathrm{X}$ " SÓLO UNA OPCIÓN, la que más se parezca a lo que pasa en su familia

1. En mi familia cuando mis hijos quieren salir con sus amigos:

( ) Se decide el permiso, según su comportamiento y el cumplimiento de sus obligaciones y tareas.

() Tienen que cumplir sus obligaciones y pedir permiso. Si se exceden hay consecuencias.

( ) Depende con quién, y a dónde vayan a salir, sólo deben avisar.

2. En mi familia, si mis hijos salen y llegan después del tiempo establecido:

( ) Se les pregunta por qué llegaron tarde y dependiendo de la respuesta hay una consecuencia.

( ) Depende de la hora que lleguen se les llama la atención.

( ) Como saben que hicieron mal, se les pide explicaciones y su falta tiene consecuencias. 
( ) No reprobar y portarse bien.

() Portarse bien y sacar buenas calificaciones ya que es su obligación.

() Cumplir con sus responsabilidades de la mejor manera posible.

4. Si mis hijos no cumplen con las tareas escolares:

( ) Se les limitan sus actividades favoritas hasta que obtengan mejores calificaciones, bajo un acuerdo.

() Se les suspenden sus salidas y se aumentan sus horas de estudio.

() Se les dice que deben mejorar y que se esfuercen.

5. En mi familia, se espera que mis hijos fuera de casa:

( ) Se comporten libremente de acuerdo a su responsabilidad, sin faltar a ninguna regla

( ) Respeten todos los valores, normas y reglas que se les han inculcado.

( ) Se comporten de acuerdo al lugar donde estén y que asuman las consecuencias positivas o negativas de su comportamiento.

6. Cuando mis hijos tienen algún conflicto fuera de casa:

( ) Se pide que expliquen la situación y dependiendo de ésta se decide si es necesario intervenir.

( ) Según las normas de la casa, se analiza y se corrige la situación de la mejor manera posible.

() Se les da la libertad de solucionar sus conflictos con los consejos que se les han dado.

7. Lea las siguientes afirmaciones y marque con una " $\mathrm{X}$ " SÓLO UNA OPCIÓN, la que más se parezca a lo que pasa en su familia

( ) En mi familia todos sabemos lo que hacemos y dónde andamos.

( ) En mi familia nos reunimos todos los fines de semana, además cuando tenemos tiempo compartimos diferentes actividades y experiencias con toda la familia.

( ) En mi familia es muy importante darnos tiempo para platicar unos con otros, durante el tiempo que coincidimos en casa.

8. Lea las siguientes afirmaciones y marque con una " $\mathrm{X}$ " SÓLO UNA OPCIÓN, la que más se parezca a lo que pasa en su familia

( ) En mi familia el afecto fisico como abrazos, besos, etc., lo demostramos en fechas especiales como cumpleaños, logros obtenidos, navidad, etc.

( ) La comunicación y el tiempo que compartimos en mi familia lo complementamos con muestras de afecto físico como besos y abrazos.

( ) En mi familia el amor no se demuestra con besos y abrazos, sino con acciones y una de ellas es compartir nuestro tiempo juntos y platicar.

9. Lea las siguientes afirmaciones y marque con una " $X$ " SÓLO UNA OPCIÓN, la que más se parezca a lo que pasa en su familia

( ) Cuando se necesita hablar de algo y resolver una situación en mi familia buscamos el tiempo para hacerlo.

( ) En mi familia siempre hay tiempo para darnos mucho afecto y compartir nuestras, ideas, problemas y preocupaciones.

( ) En mi familia siempre buscamos el tiempo para compartir nuestras ideas, problemas y preocupaciones.

10. En mi familia, para que mis hijos triunfen en la vida:

( ) Se les motiva platicando con ellos para que logren lo que se proponen y se les apoya cada que lo piden.

( ) Se les permite que forjen su propio futuro, $y$ tomen sus decisiones responsablemente.

( ) Se toma en cuenta sus gustos e intereses y se les apoya para que los lleven a cabo, y además cumplan con sus responsabilidades.

11. En mi familia, nos damos cuenta que mis hijos están progresando o teniendo éxito:

( ) Estando al pendiente de las actividades que realizan.

(1) Escuchando el nivel de satisfacción que sientan al realizar lo que se proponen.

() Preguntando cómo se sienten y escuchando su opinión respecto a lo que deben hacer.

12. En mi familia, sabremos que mis hijos han triunfado cuando:

( ) Han logrado realizar lo que se propusieron.

( ) Han cumplido con sus planes y expectativas de acuerdo a sus intereses.

( ) Han encontrado satisfacción en lo que hacen.

13. Enumere del 1 al 4, por orden de importancia, los siguientes aspectos que relaciona usted con el éxito. Asignando estos valores: 1 . Indispensable 2. Muy importante 3. Medianamente Importante 4. No tan Importante

Económico-Laboral ( ) Social-Familiar ( ) Valores-Felicidad ( ) Académico-Profesional ( )

IGRACIAS!

Figure 3 - Presentation of the Final Instrument: identifying information

\section{DISCUSSION}

In today's society, the family is among the most important institutions in terms of education. Recently, given the lack of sense of family in relation to phenomena such as globalization and post modernity information society, the family constitutes a component of research interest in both sociology and anthropology and in education and psychology. This interest in the family involves seeking elements that can link the same institution as familiar with other school institutions. Addressing this line of research involves abandoning family-obeyed proposals, as well as familiar and accurate models defined by society to which they belong. However, the characteristics of the new society urge research models to propose new mechanisms and processes that enable exploratory visualization and new family models produced by the novel roles and functions of its members and their relations and internal mechanisms. Additionally, these new processes may allow redefined dimensions and factors involved in family dynamics and parenting patterns, attachment bonds and new patterns of success that are configured in different and familiar models. In a recent study concerning the families, such as an analysis category, the research contribution on family nursing included the illness experience in the context of care and interventions. The increased family research in nursing studies demands consideration regarding the research quality, in view of the complexity of 
studies that address the family. We discover that researching family represents more than defining a unique group of study, the tropology area; psychology area disciplines have focused on rediscovering the importance of entering this field of research ${ }^{(12)}$. Browsing this material from a qualitative and attributional perspective involves approaching the phenomenological features of those driven theoretically to mediate the actions and new parental models.

\section{CONCLUSION}

Amid the current social phenomena, where young people are forced to make decisions autonomously, be self-regulated, and become involved in situations whereby decisions in turn reflect a familiar reference preceding it, it is necessary to analyze and intervene in family dynamics. Because the family constitutes the first educational experience that forms the child from his or her birth, the family provides the child a wealth of information, which is subsequently enhanced by other social and institutional sources. Hence, it is necessary to know the parenting patterns, attachment bonds and patterns of success that par-

\section{REFERENCES}

1. Santillán MM; Instituto Interamericano del Niño, la Niña y Adolescentes; Organización de los Estados Americanos. Sistema de monitoreo de Derechos de la Infancia: estado de situación en la región, menú de indicadores, propuestas para su implementación [Internet]. Montevideo: IIN; 2012 [citado 2013 set. 23]. Disponible en: http://www.iin.oea.org/IIN2011/ documentos/INFORME\%20FINAL\%2OINDICADORES\%20 201212.pdf

2. Palacios J, Moreno M. Contexto familiar y desarrollo social. En: Rodrigo López MJ, coord. Contexto y desarrollo social. Madrid: Síntesis; 1994. p. 157-88.

3. Clemente R, Hernández CB. Contexto de desarrollo psicológico y educación. Málaga: Aljibe; 1996.

4. Ribeiro LM, Medeiros SM, Albuquerque JS, Fernandes SMB. Mental health nursing and the Family Health Strategy: how the nurse is working? Rev Esc Enferm USP [Internet]. 2010 [cited 2013 Oct 16];44(2):373-9. Available from: http://www. scielo.br/pdf/reeusp/v44n2/en_19.pdf

5. Papalia D, Wendkos S, Duskin R. Desarrollo humano. Ciudad de México: Mc Graw Hill; 2005.

6. Tenorio M. Estilos de autoridad paternal. En: Universidad del Valle, Psicología Cultural [Internet]. 1999 [citado 2013 set. 22]. Disponíble en: http://psicologiacultural.org/Pdfs/ Materiales/Ponencias/Estilos\%20de\%20autoridad.pdf ents now encourage in their homes and to be aware of the educational references that are provided to children to prepare them in their daily personal decision-making and social behavior.

With the implementation of Attributional Questionnaire for the Exploration of Parental Models in the present study, it is possible to obtain information on the factors involved in the different parenting models in parents of Mexican families. The questionnaire allows us to generate action guidelines through family education programs to redirect or consolidate existing parental models to produce more effective ones, to promote healthy emotional relationships, to live together without violence, to respect the social norms and limits without minimizing individuality and autonomy, and to create a motivation toward shared success and common welfare. This area of study and intervention will impact other areas, not only family relations with young people. Shifting the patterns of behavior and effective relationships generated at home to other related groups will allow young people to attend social activities in a self-regulated way, thus enhancing the vision of success in the professional, academic and social arenas.

7. Scheuer N, Pozo Jl. Las concepciones sobre el aprendizaje como teorías implícitas. En: Pozo Jl, Font CM, coords. El aprendizaje estratégico: enseñar a aprender desde el currículo. São Paulo: Santillana. 1999. p. 87-108

8. Rodrigo López MJ. Etapas, contextos, dominio y teorías implícitas en el conocimiento social. Rodrigo López MJ, coord. Contexto y desarrollo social. Madrid: Síntesis; 1994. p. 26-46.

9. Camacho J, Correa AD. Diseño de una metodología para el estudio de las Teorías Implícitas. En: Rodrigo MJ, Rodríguez A, Marrero J, coords. Las teorías implícitas: una aproximación al conocimiento cotidiano. Madrid: Visor; 1993.

10. Ruíz C. Instrumentos de investigación educativa: procedimientos para su diseño y validación. Barquisimeto: CIDEG; 2002.

11. Buendía L. Técnicas e instrumentos de recogida de datos. En: Colas M, Buendía L. Investigación educativa. Sevilla: Alfar; 1998. p. 201-48.

12. Ângelo $M$, Bousso RS, Rossato $L M$, Damião $E B C$, Silveira $A O$, Castilho AMCM, et al. Family as an analysis category and research field in nursing. Rev Esc Enferm USP [Internet]. 2009 [cited 2013 Oct 16];43(spe 2):1337-41. Available from: http:// www.scielo.br/pdf/reeusp/v43nspe2/en_a33v43s2.pdf 